Page 57-64. ISBN: 978-602-6 988-75-1

Web Jurnal Online: jurnal.unmuhjember.ac.id

By: Kiki Endah; Irfan Nursetiawan; R. Rindu Garvera

Galendo Taste Acculturation as a New Icon Village Special Food

\title{
GALENDO TASTE ACCULTURATION AS A NEW ICON VILLAGE SPECIAL FOOD
}

\author{
By: Kiki Endah, Irfan Nursetiawan, R. Rindu Garvera \\ Universitas Galuh, Ciamis, Indonesia \\ email:kiki_spt@yahoo.co.id
}

\begin{abstract}
The purpose of this study is to find out the existence of a regional specialty in maintaining economic stability in rural areas and improving the welfare of the people in Ciamis Regency. The method used is a qualitative descriptive research method and through a data triangulation approach. The results of the study show that galendo as typical food from Ciamis Regency still shows its existence and is still sustainable today. But to boost the popularity of these foods, craftsmen innovate their taste so that the various flavors of the galendo product emerge. The galendo flavor variant has an impact on increasing sales. Despite the many variants of the galendo, it still retains the flavor of the galendo itself. And this certainly contributes to increasing the selling value of raw materials for making galendo in the community of Ciamis Regency.
\end{abstract}

Keywords: Acculturation, New Icon, Traditional Food, Galendo. 


\section{INTRODUCTION}

The potential of natural resources found in rural areas will have economic value if rural communities are able to process existing raw materials from that potential. The abundance of natural resources in rural areas, in fact, does not make rural communities all of Sumatra. The equal distribution of development expected by the community has not been realized in several villages in Indonesia. This has led to perceptions of villagers who are marginalized and rarely touched by development. Local wisdom that grows as a social and cultural condition in rural communities is also one of the factors that support community-based cultural preservation. The values of local wisdom that are still sustainable will also have an impact on natural sustainability and prevent natural damage caused by the exploration of natural resources carried out by rural communities. The potential of existing natural resources should have an impact on people's welfare. But a solution is still needed to process these natural resources into the economic potential for the community.

The same goes for the natural resource potential in Ciamis Regency and is dominated by coconut plantations. Ciamis Regency ranks seventh with an area of $32,647,000 \mathrm{Ha}$ and the total production of 19,998,000 tons in 2016 (jabar.bps.go.id, 2016). With this potential, it opens opportunities for the community to use natural wealth in the form of coconut so that it can change the family economy for the better. If you see the amount of production which reached 19,998,000 tons in the past few years means that farmers still depend on their income through coconut products.

Coconut as a raw material for making coconut oil is indeed found in Ciamis Regency and is relatively abundant, but this is inversely proportional to the number of coconut oil craftsmen who tend to be less. The coconut oil craftsmen that still survive today rely on galendo sales. Galendo is a by-product of coconut oil making and has a high economic value. The existence of galendo has become a typical food from Ciamis Regency and has been known to several regions in Indonesia, and is usually used as a souvenir by tourists visiting Ciamis Regency. This typical food has helped coconut oil craftsmen to survive amid the fluctuating level of galendo sales. The current conditions for the number of coconut oil craftsmen in Ciamis Regency are relatively few. Some of them are spread in several regions, such as in the Cigembor Subdistrict, there are 3 (three) craftsmen and in Ciamis Village there is 1 (one) craftsman.

The small number of coconut oil craftsmen has resulted in a decrease in the amount of production from galendo. Some coconut oil producers in Ciamis Regency are dominated by disadvantaged people, especially workers. In addition, the number of coconut plantations from year to year has declined due to the conversion of plantations which are used as residential land. This causes the complexity of the dynamics of galendo oil producers who have an impact on the number of various processed products from galendo.

Various preparations from Galendo have placed galendo as a typical food from Ciamis Regency. Galendo which has a distinctive taste and is classified as a snack that comes from the pulp of coconut oil making, now the number of sales has decreased. This is caused by the form and presentation of galendo which is still conventional. Therefore there needs to be innovation in the processing of various flavors of galendo using raw materials that are easily found in the Ciamis Regency area. With a lot of flavor in galendo processed, it will be able to increase the economic selling value for the community and will also give consumers a taste variant and will be more familiar with Ciamis Regency as a regional center that produces good quality galendo and has diverse tastes. And this will be an attraction for tourists in addition to enjoying natural wealth and specifically looking for galendo special food that can be brought home as a souvenir. 
Specialty in food is one proof of interaction in a culture that comes from the authenticity of local wisdom. Specialty in a product, both in terms of taste, shape, size, and name embedded into a character that can not be separated from communication between people who know the existence of these products. In the current modern era, the attention and existence of traditional foods are decreasing due to new trends related to the presence of new foods originating from abroad. The existence of traditional foods will be increasingly threatened, if not preserved.

The industrial era 4.0 has also been one of the factors driving the arrival of food products originating from abroad. Food enthusiasts from abroad appear to be increasing and this is evidenced by the increasing number of food outlets selling typical foods from abroad. This is also unusual because traditional food enthusiasts are now turning to more modern foods. The sophistication of technology, as well as the rapid development of the internet, have made the era of free markets increasingly developing. If you don't do educative and preventive steps towards these conditions, it will cause the loss of traditional local food in the community.

\section{FOOD INNOVATION}

In general, the meaning of innovation is related to ideas, ideas, and products that do not yet exist and can be implemented in daily life. This means that innovation must provide a positive benefit and impact for the general public. Innovation is a broader concept that addresses the application of new ideas, products, or processes. New ideas will bring out something innovative if the ideas and ideas are oriented to the quality of the products produced.

In line with this, innovation can be said to be a social and economic success thanks to the introduction or discovery of old ways of transforming input into output in such a way that it successfully creates major changes or drastic changes in the relationship between use value or benefit value. Innovation is also a tool to replace the old with something new. Innovation is the ability to create something new and different from the previous situation, and certainly in accordance with ideas, facts and information that already exists. Innovation products generally show new, quality, and beneficial qualities. So that innovation is essentially new and qualitative.

Similarly, the existence of galendo at this time has undergone a transformation in terms of shape, size, and taste. The transformation that occurs in a food product is caused by a marketing orientation that focuses on consumers of food lovers themselves. The essence of a change that occurs is caused by the creation of images and marketing techniques so that these foods can reach consumers, and are in demand by the public. This is in line with the opinion of Kohli and Jaworski (in Mohamad Y.A, 2010) stating the core marketing focus on consumers and coordinated marketing. This means that the orientation in terms of marketing a product must be able to satisfy the desires of consumers.

Marketing activities are not always directly proportional to positive growth in terms of business, because marketing activities sometimes do not match what has been planned. According to Philip Kotler (in Kurnia. E, 2013: 27) states, Marketing is a human activity that is directed to meet needs and desires through an exchange process, where there are 3 (three) formulas, namely products, places, and promotions. There are two interesting things in marketing, especially as part of food innovation, namely products and promotions. The product as an object of the subject's assessment, that is, the consumer, of course, must have the characteristics and novelty to follow the tastes of the consumer. In essence, consumers always learn and sometimes compare products with one another, both in terms of quality and price. 
In addition, for promotional activities as an attraction for consumers, they must be targeted and on target. Promotions that can be done in the era of internet development are usually done digitally. The promotion technique is known as internet marketing. The development of the internet and even the existence of social media in terms of promotion of a product greatly facilitates its users. Today's social media is not just a medium for interacting online but can be used as a media campaign. Even with the existence of social media the internet community is slowly being formed or often referred to as netizens. Netizens are active on several existing social media platforms, and often comment on a product and even summarize and recommend some foods. So that social media can also be used as a reference about the tastes desired by the community for certain foods.

With the concept of food that is always adaptive to the times, then these foods can remain sustainable. Likewise with galendo as a typical food derived from the technique of making traditional coconut oil, of course, must be able to be adaptive and in accordance with the times. Packaging and promotion of galendo must be done in a modern or contemporary manner that allows reaching the tastes of the community. Attractive packaging without reducing a product's quality will make the product preferred by the community. In addition, a promotion that is right on target will make it easier for products to be known by the public. The point is innovation from food, not only a matter of form, taste, aroma but also related to the packaging of food products and of course, must be adaptive to development. This allows the existence of regional specialties to be maintained and sustainable.

\section{TRADITIONAL FOOD IN CIAMIS REGENCY}

Food is an important need for all humanity. Food is needed as building energy for the body and as a substance that can make metabolism better. Like other regions in Indonesia that have traditional food, Ciamis as one of the districts in the eastern Priangan region also has diverse traditional foods. Like a combo made from cassava base, bananabased banana sale, a pancake is made from the basic ingredients of cassava and grated coconut and galendo made from coconut-based ingredients. Traditional food is a characteristic that is owned by an area that is made and is a food that is passed down from generation to generation which is usually eaten by members of the local community. Traditional food as a characteristic of an area is an asset that can lift and introduce the region and raise the economic value of the family.

Traditional food or local cuisine is a food product that is often consumed by a community group or served at certain times and celebrations, inherited from generation to generation, made according to recipes from generation to generation, made without or with a little engineering, and having certain characteristics that distinguish it from other regional cuisines. Traditional galendo food is an easy food to get in the Ciamis Regency area, with coconut-based ingredients that can be enjoyed with warm rice eaten for breakfast or during the daytime. Galendo by some modern societies is now used as a snack or snack. But there needs to be innovation from galendo various flavors so that consumers can feel the different flavors of the original galendo.

This makes Ciamis Regency has a variety of foods made from galendo. One of them, namely dage as a traditional food made from galendo. Dage is food served with rice and is a favorite for people in rural areas. According to Masduki, Aam (2012) there are several traditional foods typical of Ciamis Regency, including: apem, angleng, galendo, abon, cuhcur, mustopa, sale of banana, cassava chips, colok gemrung, opaque sticky rice, saroja, bugis sticky rice, ulen, ranginang, banana chips, cimpring / kicimpring, nagasari, satay, kalua oranges, kolontong, and sticky rice cake. Of these traditional foods, galendo is a traditional food that is an icon of Ciamis Regency. 
Galendo even though it is included in traditional food, but has now been transformed into a more modern food. According to Masduki, Aam (2012), how to process and manufacture galendo, as follows:

a. Coconut meat is cleaned, then grated with grated or machine;

b. The grated coconut is taken from the water (coconut milk);

c. The coconut is peeled and the meat is gouged and cleaned;

d. Coconut milk is cooked until it boils until the water runs out, then clumps, and becomes galendo which mixes with oil;

e. Galendo powder is removed and stored in the mold and then wrapped in woven bamboo;

f. Galendo powder is compressed by pressing it, in addition to compacting it to separate galendo from the oil; and

g. After that, the solid galendo is cut into pieces and packed. Likewise, the oil from galendo is also packaged.

Galendo as typical food and certainly has certain characteristics that are very close to processing foods made from coconut. By way of processing that is still done traditionally, making galendo has many disadvantages. One of them, namely the expiration period which is fairly fast. Then in terms of form, it is still less attractive, so innovation is needed to maintain the existence of these special foods.

\section{METHODOLOGY}

In the research conducted on food innovation, especially those related to the existence of galendo which has various kinds of flavors using qualitative descriptive research. The object of this research is the Galendo craftsmen in the Ciamis Regency area. According to Erickson (in Albito. A and Johan. S, 2018:7), states, that qualitative research seeks to find and describe narratively the activities carried out and the impact of actions taken on their lives. So that this study uses data collection techniques by means of literature studies, observation or observation and documentation.

\section{RESULTS AND DISCUSSION}

A form of local wisdom does have certain characteristics and of course, each region has that. Similarly, the existence of traditional foods is unique in terms of shape, taste and of course serving as a dish. Cultural developments are quite rapid and coupled with the influence of foreign cultures make traditional food less interested. Likewise, food originating from Ciamis Regency which was once a prima donna is currently experiencing a decline in demand. Galendo as a typical food of Ciamis Regency that requires special attention so that it is still sustainable. Innovation is needed to maintain work, especially food as an icon of an area. This is in line with the opinions of Everett $\mathrm{M}$ Rogers and Floyd G. Shoemaker (in Kharisma A.F and Yuliyanto B.S, 2016) stating the diffusion theory of innovation in the process there are 4 (four) stages, namely:

a. Knowledge: individual awareness of innovation and a certain understanding of how the innovation functions.

b. Persuasion: individuals form an attitude of agreeing or disagreeing with innovation.

c. Decision: the individual engages in activities that lead to the choice to accept or reject innovation.

d. Confirmation: the individual seeks reinforcement (support) for the decision he has made, but he may turn around the decision if he obtains the contents of a statement that is contradictory. 
With the diffusion of innovations taking place in the community, Galendo remains sustainable. This is evidenced by the existence of galendo in several forms of products made from galendo. In fact, it has used several modern packaging techniques and Galendo packaging which is quite interesting. Durability will also last longer, which can last up to 3-5 months. Modern innovations can certainly help the existence of traditional foods remain and are in demand by the community. External factors turned out to be the dominant factor in the possibility of innovation in society. It can also have an impact on improving the business world as part of the economy of the community. A good business environment will cause a good result and vice versa.

According to Pearce and Robinson (in Sri, Budi C.Y, 2006) states that there are 3 (three) types of business environment, namely remote environments such as economics, social, political, technological and ecological; industrial environments such as entry barriers, supplier strength, buyer strength, substitution goods, and competition; and operating environment such as competitors, creditors, consumers, labor, and suppliers. A touch of technology is needed so that a product has a novelty value. Similarly, for galendo products, there has been a significant change.

These changes can be seen in a variety of food products made from galendo and packed with a quite attractive packaging. The sense of acculturation that is currently occurring on the galendo product has an impact on increasing sales. In addition, the existence of galendo products has made galendo products with a variety of flavors, such as galendo flavored chocolate cookies that are popular with the public. One of the most interesting innovations from Galendo, namely the emergence of galendo products originating from a blend of western culture with the culture of local wisdom of an area. The product is named Galecok (Galendo Cokelat). The product is real chocolate which is given galendo filling in it.

With the presence of new products, it is expected to improve the economy, especially for traditional galendo craftsmen. In addition, the new product is expected to make it survive in the era of globalization and competitiveness between countries that have now been felt. The motivation of craftsmen to become more creative and advanced is one of the basic capital that must be owned. Because for the food industry in Indonesia, there are enough opportunities. This is in line with Dwi's opinion, Gemina. Et al. (2016) states, that there are supporting factors in the food industry, namely (1) a large number of people who are the market for food industry products, (2) increasing income levels that drive demand for processed food products, (3) most raw materials production is sufficiently available domestically, (4) sufficient availability of workers with relatively low wages, and (5) production capacity of some food industry businesses that can still be improved.

This is an opportunity for marketing a food product, as well as foods made from galendo that persist and experience changes in terms of taste. Where market opportunities in Indonesia are still open and with a note that the quality and quantity of production can be increased. The existence of raw materials in making galendo can also be said to be abundant. Because almost all regions in West Java produce coconuts. So to increase production in making galendo it is very possible. However, in terms of marketing, galendo still has problems. Because of Galendo's orientation as a souvenir, galendo marketing is limited to some souvenir shops. This is what blocks the marketing of galendo products.

In addition, the fluctuating price of raw materials al so affected the selling price of the galendo itself. Then to demand galendo products are also almost the same, meaning the number of requests each month is different. So that it is necessary to preserve traditional foods so that they still exist and are not extinct by the times. There are several 
solutions for preserving traditional foods. According to Novia, Rochmawati. Et al. (2013) stated that food preservation efforts were carried out by: (1) research; (2) publications; (3) festivals; and (4) entrepreneurship. Research on these food products can help to identify food products and of course as material for academic studies in the effort to preserve traditional foods. A publication is also needed to introduce traditional food to the public and with a note that the food can be known as an icon of an area. Then many traditional foods have been introduced through several festival activities. This is not enough to help in preserving traditional foods. Extra effort is needed in the preservation of traditional food so that its existence is still there. Community empowerment through entrepreneurship can be said as a concrete step in the effort to preserve these traditional foods.

Based on this, good management is needed in terms of production to marketing to consumers. The factor of human resources is the main problem that must be handled. Because human resources will determine the power of innovation and the level of production in an industry, especially in the food industry. Food industry owners and employees can collaborate to improve the quality and quantity of food product production. This is in line with Layla. K and Lindawati. K (2014) states, that owners or managers form discussion forums regularly to express opinions, ideas, criticisms, and comments from employees. Discussion forum activities focused on improving performance. Discussion of the discussion can be about marketing methods (internet marketing, personal branding training, marketing strategies through a promotion) and production methods (product quality improvement and work safety). In marketing, the method requires that all employees (divisions) work together with the company as a team to serve customers, so as to increase sales with agreed marketing concepts.

Thus the potential to develop in food production is very open. The existence of food in the community depends on the advantages and presentation which is an added value for the food. This is what Galendo craftsmen are trying to offer galendo in various flavors that are modern and acceptable to all people. Innovation and creativity have never been separated, and this has become the main capital to improve traditional food marketing.

\section{CONCLUSION}

Based on the discussion in the research that has been carried out it can be concluded, that:

a. The existence of Galendo has made the food an icon of traditional Ciamis Regency traditional food.

b. Acculturation in traditional food occurs due to cultural exchanges between nations and produces a more dynamic new culture.

c. Innovation and creativity are the main capital in making a new breakthrough in the traditional food industry.

d. The taste innovation for galendo has an effect on increasing sales and also has an impact on increasing demand for raw materials for making galendo.

e. Galendo as a food characteristic of Ciamis Regency can play a role in empowering rural communities. 
Proceeding ICOGISS 2019

Page 57-64. ISBN: 978-602-6 988-75-1

Web Jurnal Online: jurnal.unmuhjember.ac.id

By: Kiki Endah; Irfan Nursetiawan; R. Rindu Garvera

Galendo Taste Acculturation as a New Icon Village Special Food

\section{References}

Albito. A dan Johan. S. 2018. Metodologi Penelitian Kualitatif. Sukabumi: CV. Jejak.

Dwi, Gemina. Dkk. 2016. Pengaruh Motivasi Usaha terhadap Keberhasilan Usaha dengan Kemampuan Usaha sebagai Variabel Mediasi pada Industri Kecil Menengah Makanan Ringan Priangan Timur-Indonesia. Jurnal Manajemen Teknologi.15.(3). 297-323.

Kharisma A.F dan Yuliyanto B.S. 2016. Komunikasi dalam Difusi Inovasi Kerajinan Eceng Gondok di Desa Tuntang Kabupaten Semarang.The Messenger.8.(1).

Kurnia. E. 2013. Customer is Change: Eksplorasi Perilaku Pelanggan di Tengah-tengah Gaya Hidup Digital. Jakarta: BUKUREPUBLIKA.

Layla. K dan Lindawati. K. 2014. Pengaruh Modal Insani dan Modal Sosial terhadap Kinerja (Studi Kasus Usaha Kecil dan Menengah (UKM) Makanan dan Minuman Kota Bogor. Jurnal dan Manajemen Organisasi.5.(3). 244-257.

Masduki, Aam. 2012. Makanan Tradisional di Kabupaten Ciamis.Patanjala.4.(2).89-99.

Mohamad Y.A. 2010. Pengaruh Orientasi Pasar, Intellectual Capital, dan Orientasi Pembelajaran terhadap Inovasi: Studi Kasus pada Industri Hotel di Jawa Timur. Integritas (Jurnal Manajemen dan Bisnis).3.(3).317-329.

Novia, Rochmawati. Dkk. 2013. Penelusuran Jejak Makanan Khas Semarang sebagai Aset Inventarisasi dan Promosi Wisata Kuliner Jawa Tengah. DIPO IPTEKS.1. (1).8-11.

Sri, Budi C.Y. 2006. Analisis Perubahan Lingkungan Terhadap Kompetensi Usaha (Studi Pada Pengusaha Makanan Dan Minuman Skala Kecil Dan Menengah Di Kabupaten Malang Dan Pasuruan). Humanity.1.(2).106-116. 